\title{
Social Media Adoption by Health Professionals: A TAM-Based Study
}

\author{
Md Irfanuzzaman Khan *, M Abu Saleh and Ali Quazi
}

check for

updates

Citation: Khan, M.I.; Saleh, M.A.; Quazi, A. Social Media Adoption by Health Professionals: A TAM-Based Study. Informatics 2021, 8, 6. https://doi.org/10.3390/informatics 8010006

Academic Editor: Antony Bryant

Received: 23 November 2020

Accepted: 6 January 2021

Published: 29 January 2021

Publisher's Note: MDPI stays neutral with regard to jurisdictional claims in published maps and institutional affiliations.

Copyright: (C) 2021 by the authors. Licensee MDPI, Basel, Switzerland. This article is an open access article distributed under the terms and conditions of the Creative Commons Attribution (CC BY) license (https:/ / creativecommons.org/licenses/by/ $4.0 /)$.
Canberra Business School, University of Canberra, Canberra 2617, Australia; abu.saleh@canberra.edu.au (M.A.S.); ali.quazi@canberra.edu.au (A.Q.)

* Correspondence: irfan.khan@canberra.edu.au

\begin{abstract}
This research identifies the underlying drivers impacting on healthcare professionals' social media usage behaviours using the technology acceptance model (TAM) as the theoretical lens. A self-administered survey questionnaire was developed and administered to 219 healthcare professionals. Data are analysed applying the structural equation modelling (SEM) technique. The SEM model demonstrated an acceptable model fit $\left(\chi^{2}=534.241 ; \mathrm{df}, 239, \chi^{2} / \mathrm{df}=2.235\right.$, RMSEA $=0.06$, $\mathrm{IFI}=0.92, \mathrm{TLI}=0.93$, and CFI $=0.92)$ and indicates content quality, perceived risk, perceived credibility, peer influence, confirmation of expectations, supporting conditions, and perceived cost significantly influence the notion of perceived social media usefulness. Furthermore, perceived social media usefulness positively affects social media usage behaviour of healthcare professionals. This research generates important insights into what drives the adoption of social media by healthcare professionals. These insights could help develop social media guidelines and strategies to improve the state of professional interactions between health professionals and their clients.
\end{abstract}

Keywords: social media; healthcare professionals; privacy threat; credibility; perceived usefulness; technology adoption; technology adoption model

\section{Introduction}

In the healthcare domain, social media has transformed our interactions with one another through community building, message amplification, rapid dissemination, and active engagement [1]. Social media offers healthcare organisations an abundance of potential benefits [2-4]. These benefits include patient engagement, social support and enhanced community outreach, health message implications, and improved quality of patient care [5,6]. In a practical sense, social media is leading a true revolution in the healthcare industry [7]. Extant literature suggests that social media can help healthcare professionals promote and advertise their products and services locally and globally [8-12]. Various healthcare social media sites make it easier for consumers to locate the products and services they want to find. For example, PatientsLikeMe is a web-based application, built on the philosophy of value-based care, and it allows the user to share in-depth quantifiable data about health conditions, symptoms, and possible treatments. Users can learn from the experience of other patients and improve their health outcomes. These data are provided to members through graphical health profiles and combined into reports accessible on-line. Members can discuss the datasets either within a group forum or individually through private messages [13].

However, social media also poses significant challenges to the healthcare domain, particularly with reference to privacy and safety considerations for both patients and healthcare professionals [14]. Existing studies also highlight misinformation and disinformation, organisational resistance, privacy threats, inefficiency, adverse health consequences as significant challenges emerging when applying social media in the healthcare sector [15-22]. For example, in a survey of US medical school administrators, it was discovered that $60 \%$ reported incidents in which medical students exhibited unprofessional conduct, and $13 \%$ 
reported violations of patient confidentiality [15]. However, it is still unknown how the above challenges influence health professionals' perceptions regarding the use of social media in the healthcare setting.

Research on the usage patterns revealed mixed results. While the use of social media by both health professionals and public is on the increase, there are considerable concerns about its usefulness in a healthcare setting [23]. Recent findings suggest that despite the advances made by social media in the healthcare domain, many medical professionals are reluctant to use it for health communication [24-26]. The question is: What are the factors influencing health professionals' perceived usefulness social media?

The primary aim of this research is to understand the factors affecting the perceived usefulness of social media usage from the perspective of health professionals. The following section introduces the theoretical background and focuses on the dearth of theory-based research on social media in the healthcare context.

\subsection{Theoretical Background and Research Model}

Extant social media-related research in healthcare is built on either a standard survey of medical professionals or exploratory studies without a strong theoretical underpinning $[10,27]$. This study proposes an updated theoretical framework for investigating the antecedents of perceived usefulness to healthcare professionals' social media usage. The proposed framework derives from the Technology Acceptance Model (TAM) [28]. TAM has been a dominant model in the domain of technology acceptance. The TAM has gained considerable reputation, particularly due to its transferability to various contexts and samples, its potential to explain variance in the intention to use or the use of technology, and its simplicity of specification within structural equation modelling frameworks $[29,30]$. Besides, TAM is a powerful vehicle to understand the acceptance of healthcare technologies [31] and other generic studies concerning technology adoption [32].

The theoretical basis of the TAM is the theory of reasoned action [33] and it denotes that the antecedents of technology usage occur because of two fundamental factors: the perceived usefulness (PU) and perceived ease of use (PEOU) of a technology [34]. Perceived usefulness refers to the extent a user believes that using a particular system will improve how they do their job. Perceived ease of use (PEOU) refers to the extent a potential user expects that the target system to be free of unproductive effort [34]. The model explains that perceived usefulness and perceived ease of use influence the user's attitudes toward using a certain technology (intention). In turn, intentions to use will determine whether a person will use the application or not. However, several TAM-based studies recommended the exclusion of attitude from the model. For instance, the revised TAM model (i.e., TAM without the attitude construct) has been validated in several user technology acceptance/adoption investigations because attitude did not appear to mediate fully the effect of perceived usefulness and perceived ease of use on behavioural intention as originally anticipated [35-37]. Thus, in this study, the construct "attitude" was excluded from the examination of healthcare professionals' social media usage behaviour.

Previous studies concerning information system (IS) and information technology (IT) adoption has consistently accepted perceived usefulness (PU) as the most influential determinant of an individual's decision to adopt a new technology [38,39]. Extant literature indicates that the influence of PU is greater than that of PEOU concerning the adoption of new technology [40]. In the health technology domain, physicians adopt a more pragmatic attitude to acceptance. They focus on the usefulness of health technology adoption rather than on the ease of using it [41]. Consequently, health professionals concentrate more on system utility and functionality than users in other industries. Therefore, their motivation for a new technology acceptance is directly related to the fact that the new technology acts as an enabler of their daily tasks. Furthermore, PU has a greater impact on behavioural intention to use than PEOU [42]. Prior studies that employed TAM have demonstrated that PU the most important predictor of behavioural intention to use new technology, while perceived ease of use becomes less important over periods of sustained usage [43]. 
Therefore, the construct PEOU is not considered in the proposed theoretical framework, leading to the inclusion of PU as the fundamental predictor of health professionals' social media usage behaviour.

Although PU is well accepted as the major antecedent affecting technology usage behaviour, it is necessary to examine the determinants of PU in the context of social media usage in the healthcare domain. In our quest for identifying and validating the antecedents of health professionals' perceived usefulness of the social media within the healthcare context, the proposed framework contextualises the TAM by adding variables to study the impact of content quality, perceived credibility, perceived risk, peer influence, supporting conditions, confirmation of expectations and perceived cost on health professionals' social media usage behaviour. It is evident that the integration of external variables is a common trend in this research field [44,45]. An added variable approach enables researchers and practitioners to understand the drivers of intention better and assist in developing new theories [46]. The conceptual framework depicts the possible effects of the factors influencing health professionals' perceived usefulness and social media usage behaviours. These factors are yet to be contextualised and tested within the healthcare social media context. To sum up, the proposed theoretical framework is an important addition to the mainstream social media adoption literature. Figure 1 illustrates the conceptual research model.

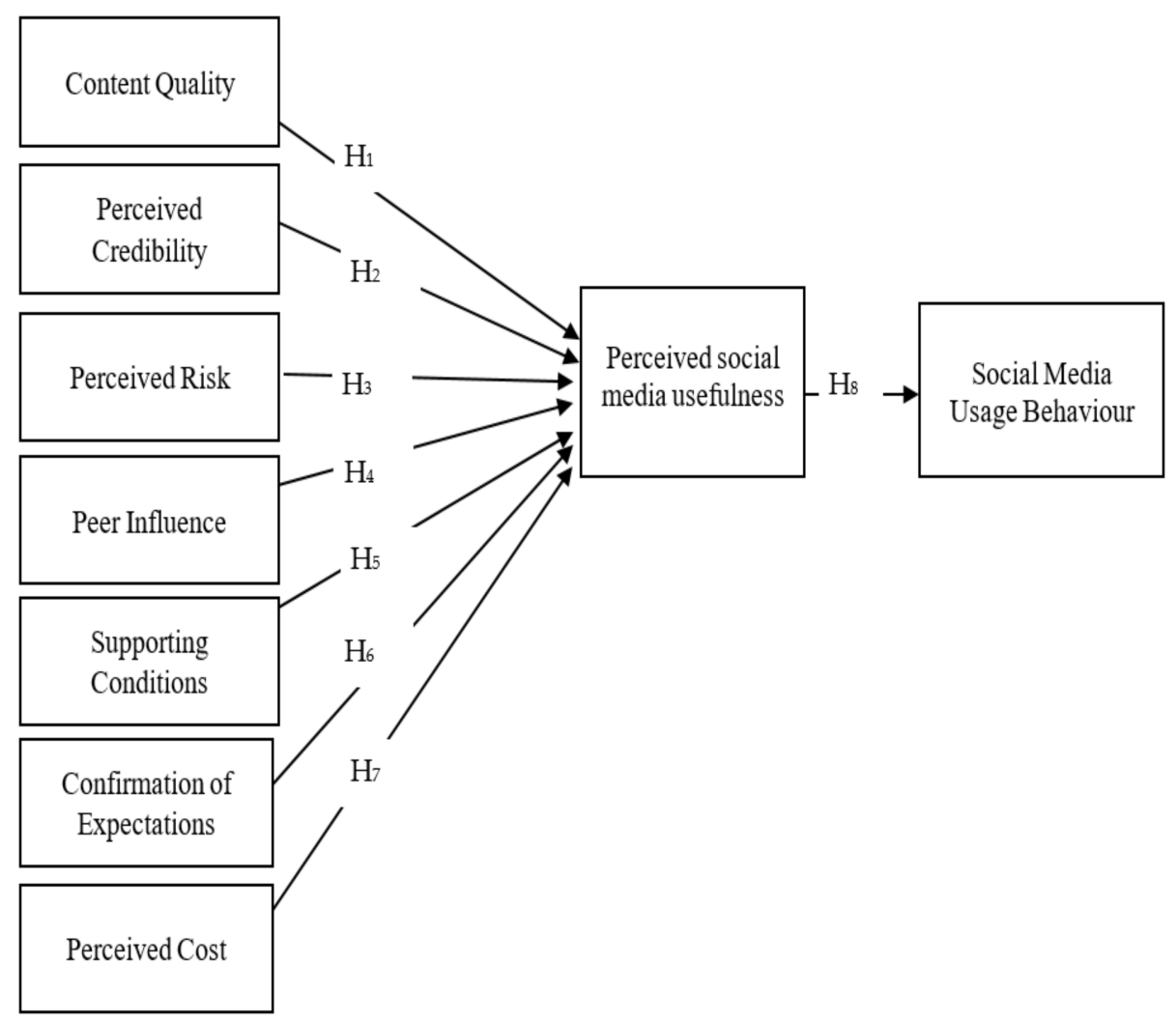

Figure 1. Social Media Adoption model.

\subsection{Hypothesis Development}

\subsubsection{A. Content Quality}

Content quality refers to social media content that is appropriately customised, relevant, easy to understand, complete, and secure during an online transaction [47]. The theoretical underpinning of this research is based on the information system success model which describes information quality as an antecedent of system use [48]. Scholars have previously found that barriers to social media included poor quality and the lack of reliability of health information [6,49]. Medically incorrect information has resulted in "wrong" instructions and contributed to serious negative outcomes. Thus, this creates a cascading 
effect which leads to the distrust of online social applications and services in medical healthcare $[50,51]$. Prior studies have consistently confirmed that information quality is a fundamental construct in evaluating the usefulness of a new system [52,53]. However, the effect of social media content quality on health professionals' social media usage decision is not very clear and warrants further investigation. Thus, we propose the following hypothesis:

Hypothesis 1 (H1). Content quality significantly influences perceived usefulness of social media.

\subsubsection{B. Perceived Credibility}

In the online context, perceived credibility denotes feelings of confidence and security while using digital technology $[40,54,55]$. Prior studies have shown that credibility affects people's voluntary acceptance of digital transactions [40,49]. Thus, perceived credibility can be a significant factor for engaging in health information searching and related activities via social media $[56,57]$. If online participants are unsure about the credibility of the health information provided through social media channels, they may stop seeking online health information $[10,19,56-59]$. Based on extant literature we propose the following hypothesis:

Hypothesis 2 (H2). Perceived credibility is associated with the perceived usefulness of health professionals' social media usage.

\subsubsection{Perceived Risk}

Perceived risk is a frequently used variable in consumer behaviour studies and known as a multi-dimensional construct. There are six components of perceived risk and they are as follows: (i) financial, (ii) performance, (iii) social, (iv) physical, (v) privacy, and (vi) time loss [60]. Prior studies have consistently shown that perceived risk negatively influences users' intention to use IT/IS systems [61-63].

In the social media context, previous studies reported privacy and confidentiality concerns as a major deterrent of social media usage in the healthcare industry $[58,64-66]$. This is because online patient privacy breaches can result in greater harm compared to privacy breaches that occur face-to-face, especially given that online privacy breaches reach a wider audience and remain permanently online. Consequently, health professionals concerns about social media use predominantly revolve around the potential risks arising from breaching patient confidentiality $[67,68]$ or publicising unprofessional content $[69]$. For example, an assessment of 271 medical blogs revealed that around $17 \%$ included ample information for patients to identify their doctors or themselves [70]. Furthermore, a content analysis of physicians' Twitter posts (5156 tweets) revealed that $4 \%$ were potentially unprofessional, including 38 potential patient privacy violations [71]. This outcome explains why many health professionals consider the integration of medicine and social media as a daunting challenge often posing severe threats to people's privacy [72,73]. From the review, the privacy-related risks arising from social media technologies can be significant and can influence medical personnel's capacity to use social media. Therefore, the following hypothesis is proposed:

Hypothesis 3 (H3). Perceived risk negatively influences health professionals' perceived usefulness of social media.

\subsubsection{Peer Influence}

Peer influence refers to the extent to which an individual perceive that the important members of his/her social circle believe that he/she should use the new system [45]. Prior research also measured this variable in the healthcare context and reported a positive relationship with behavioural intention to use technology [74]. Close peers' personal evaluations of technological interventions tend to be more credible and help to minimise uncertainty in adoption of a new technology. Thus, in a healthcare context the subjective influence of close peers or colleagues is important [18]. The benefits of social media are 
primarily based on social aspects such as social support, patient engagement, greater interactivity and social listening $[54,56,59]$. However, empirical studies concerning the effect of peer influence on health professionals' social media adoption behaviours are relatively scarce and warrants further investigation. Thus, the following hypothesis is developed:

Hypothesis 4 (H4). Peer influence positively influences the notion of perceived social media usefulness.

\subsubsection{E. Supporting Conditions}

Supporting condition refers to the extent of broader social, organisational and technical infrastructure existing to support the use of a new system or technology [45]. Recent literature raised various concern related to supporting conditions for adopting social media in a professional setting. For example, internal and external support in terms of resources, staffing, and technical expertise is necessary for social media to be used effectively [75-78]. A survey of 366 healthcare workers in the USA revealed that healthcare workers are not familiar with their workplace policies concerning social media use, which may cause a privacy breach of confidential medical information [79]. Recent studies also highlighted the importance of supporting conditions on social media usage behaviour [80-82]. Thus, it will be interesting to observe the relationship between supporting conditions and perceived usefulness in healthcare context. Drawing on the extant research the following hypothesis has been posited:

Hypothesis 5 (H5). Supporting conditions positively influence the perceived social media usefulness.

\subsubsection{F. Confirmation of Expectations}

Confirmation is the outcome of a considerable "over-fulfilment" of initial expectations $[83,84]$. The confirmation of expectations suggests that when experiences with specific system exceed expectations, expectations exert a positive influence on satisfaction [85]. Consequently, lower expectation and higher perceived performance may lead to a greater sense of confirmation [86]. Prior studies in different contexts show that when users' actual experience exceeds their expectations, confirmation positively influences perceived usefulness [87-92]. It will be interesting to examine the relationship between confirmation of expectations and perceived social media usefulness in healthcare context. Indeed, further empirical investigation of the relationship between confirmation of expectations and perceived social media usefulness is warranted. Hence, the following hypothesis is put forward:

Hypothesis 6 (H6). Confirmation of expectations is significantly associated with perceived social media usefulness.

\subsubsection{G. Perceived Cost}

The costs associated with a new information system or technology have always been a major driver of usage behaviour. In this research, perceived cost entails health professionals' perceptions concerning the initial subscription, transaction and communication costs involved in using social media [93]. Extant research also represented perceived cost as an important variable [93-95] and supports the hypothesis that perceived cost negatively affects users' behavioural intention to use technology $[96,97]$. This research argues that social media reduces the economic, time and human costs associated with clinical practice. Thus, perceived cost is expected to be an important factor for social media adoption in a professional setting. Based on the extant research, the following hypothesis is proposed:

Hypothesis 7 (H7). Perceived cost negatively affects health professionals' perceived social media usefulness. 


\subsubsection{H. Perceived Usefulness and Usage Behaviour}

The theoretical underpinning of the usage behaviour construct is grounded on the 'actual system usage' construct which refers to the degree a user applies one or more system features to accomplish a specific task [98]. Based on TAM, perceived usefulness is expected to positively influence social media usage behaviour of healthcare professionals [28]. Prior technology acceptance studies have shown that perceived usefulness is a significant predictor of intention to use information technology $[46,97]$. In accordance with the TAM framework, the following hypothesis is proposed:

Hypothesis 8 (H8). Perceived social media usefulness positively influences health professionals' social media usage behaviour.

Table 1 below provides definitions and sources of root constructs.

Table 1. Root constructs.

\begin{tabular}{|c|c|c|}
\hline Construct & Definition & Source \\
\hline Content quality & $\begin{array}{l}\text { Inherent value and usefulness of the content provided } \\
\text { by social media platforms. }\end{array}$ & [95] \\
\hline Perceived credibility & $\begin{array}{l}\text { Refers to the degree to which a person perceives that } \\
\text { using a specific technology and system would be free of } \\
\text { privacy and security related threats. }\end{array}$ & [47] \\
\hline Peer influence & $\begin{array}{c}\text { Behavioural intention to use a new technology/system } \\
\text { is influenced by the perception of important others in } \\
\text { their social circle. }\end{array}$ & {$[45,99,100]$} \\
\hline Perceived risk & $\begin{array}{l}\text { Refers to the degree to which the user perceives that it } \\
\text { would be unsafe to utilise social media technologies. }\end{array}$ & [101] \\
\hline $\begin{array}{l}\text { Supporting } \\
\text { conditions }\end{array}$ & $\begin{array}{l}\text { Availability of required conditions to perform a } \\
\text { specific task. }\end{array}$ & [102] \\
\hline $\begin{array}{l}\text { Confirmation of } \\
\text { expectations }\end{array}$ & $\begin{array}{l}\text { Refers to the degree to which the user perceives that } \\
\text { actual performance is consistent with the expected } \\
\text { performance of an information system/technology. }\end{array}$ & [103] \\
\hline Perceived cost & $\begin{array}{l}\text { The degree to which a user perceived that it is expensive } \\
\text { to utilise a specific technology or system to perform a } \\
\text { specific task. }\end{array}$ & [104] \\
\hline Perceived usefulness & $\begin{array}{l}\text { The extent to which a person believes that using the } \\
\text { system will enhance his or her job performance. }\end{array}$ & [28] \\
\hline Usage behaviour & $\begin{array}{l}\text { Refers to the degree to which a user utilises one or more } \\
\text { system features to complete a specific task. }\end{array}$ & [105] \\
\hline
\end{tabular}

\section{Methods}

This study used quantitative technique for data collection and analysis. The major attribute of quantitative research is the use of a formal and methodical statistical technique [106]. The population for this study comprised Australian health professionals who used social media, and worked in hospitals, clinics and other clinical environments.

\subsection{Data Collection}

A quantitative survey of 219 healthcare professionals was conducted. The sampling frame was derived from publicly available online databases. In an attempt to eliminate any inherent bias, a number of measures were taken. For example, steps recommended by Ryan and Bernard [107] followed, such as ensuring that the clarity and overt judgments during questionnaire instrument preparation, data processing, entry, cleaning and different phases of analyses are monitored and undertaken. A simple random sampling method was used to select the respondents. A personalised email invitation containing the link to 
the survey was sent to 824 health professionals. A total of 219 complete responses were received with a $27 \%$ response rate.

\subsection{Data Analysis}

This research employed Structural Equation Modelling (SEM) technique to investigate the hypotheses proposed in the research model. The structural equation modelling (SEM) is a technique that embodies the observed data through some structural parameters characterized by a theoretical framework [108-110]. SEM helps to conduct a simultaneous analysis, where the relationships among multiple independent and dependent constructs are modelled concurrently. This capability differs significantly from most first-generation statistical tools such as correlation, regression and factor analysis, which can analyse only one layer of linkages between independent and dependent variables at a time [111]. SPSS Amos 25 (IBM, New York, NY, USA) statistical package was used to analyse the data. SPSS Amos software (IBM, New York, NY USA) is a preferred statistical tool to examine causal and effect relationship between a number of independent and dependent variables [112]. The source of the constructs measures is documented in Table 2.

\subsection{Construct Measures}

The survey questionnaire consisted of certain factors that influence the perceived usefulness and usage behaviour of healthcare professionals. These factors were content quality, perceived credibility, perceived risk, peer influence, supporting conditions, confirmation of expectations and perceived cost. The scales for all the constructs were adapted from prior studies, many of which have already established their reliability and validity. The language of the items was modified to reflect the measurement of these constructs for social media users. The items were measured on a 7-point Likert scale $(1=$ strongly disagree, 7 = strongly agree). Prior studies indicated that 7-point Likert scale increases scale sensitivity [113] and likely to provide a more accurate measure of a participant's true evaluation and are more appropriate for electronically distributed or unsupervised usability questionnaires [114]. Details of the construct measures and their operational indicators are provided in Table 2 below.

Table 2. Construct measures.

\begin{tabular}{|c|c|c|c|}
\hline Construct & Source & Measure & Std. Est. \\
\hline \multirow{4}{*}{$\begin{array}{l}\text { Perceived Risk }(\alpha=0.72 \\
\text { AVE }=0.72)\end{array}$} & \multirow{4}{*}{$\begin{array}{c}\text { New measures } \\
\text { based on } \\
\text { [115-118] }\end{array}$} & Risky to share data & 0.8 \\
\hline & & Information can be misused & 0.68 \\
\hline & & Might not meet expectation & 0.66 \\
\hline & & Concerned about the privacy settings & 0.74 \\
\hline \multirow{5}{*}{$\begin{array}{c}\text { Content quality }(\alpha=0.85 \\
\operatorname{AVE}=0.83)\end{array}$} & \multirow{5}{*}{$\begin{array}{c}\text { Adapted } \\
\text { measures from } \\
{[48]}\end{array}$} & Social media provides relevant information & 0.76 \\
\hline & & Social media provides reliable information & 0.81 \\
\hline & & Provide accurate content & 0.88 \\
\hline & & Provide timely and complete health information & 0.87 \\
\hline & & I am not worried about security issues & 0.82 \\
\hline \multirow{4}{*}{$\begin{array}{l}\text { Perceived credibility } \\
(\alpha=0.88, \mathrm{AVE}=0.85)\end{array}$} & \multirow{4}{*}{$\begin{array}{l}\text { Measures based } \\
\text { on [55] }\end{array}$} & Health related social media sites are credible & 0.81 \\
\hline & & I am confident in using online health platforms & 0.92 \\
\hline & & I trust online health platforms & 0.84 \\
\hline & & Colleagues influence me to use social media & 0.87 \\
\hline \multirow{3}{*}{$\begin{array}{c}\text { Peer Influence }(\alpha=0.91 \\
\text { AVE }=0.88)\end{array}$} & \multirow{3}{*}{$\begin{array}{l}\text { New measures } \\
\text { based on [102] }\end{array}$} & Patients influence me to use social media & 0.88 \\
\hline & & Friends influence me to use social media & 0.9 \\
\hline & & It is expected from healthcare professionals to use social media & 0.9 \\
\hline \multirow{4}{*}{$\begin{array}{l}\text { Supporting conditions } \\
(\alpha=0.80, \mathrm{AVE}=0.78)\end{array}$} & \multirow{4}{*}{$\begin{array}{c}\text { Adapted } \\
\text { measure from } \\
{[119]}\end{array}$} & I am encouraged participate actively in health communities & 0.72 \\
\hline & & Can reach other healthcare professionals & 0.71 \\
\hline & & Workplace encourages me to use social media & 0.81 \\
\hline & & Industry practices influence me to use social media & 0.88 \\
\hline \multirow{4}{*}{$\begin{array}{c}\text { Confirmation of } \\
\text { expectations }(\alpha=0.89 \\
\text { AVE }=0.89)\end{array}$} & \multirow{4}{*}{$\begin{array}{l}\text { New measures } \\
\text { based on [83-85] }\end{array}$} & Social media has improved relationships with patients & 0.83 \\
\hline & & Saved time in professional interactions & 0.91 \\
\hline & & Strengthened relationships with colleagues & 0.86 \\
\hline & & Ensured better healthcare service & 0.94 \\
\hline
\end{tabular}


Table 2. Cont.

\begin{tabular}{|c|c|c|c|}
\hline Construct & Source & Measure & Std. Est. \\
\hline \multirow{5}{*}{$\begin{array}{l}\text { Perceived cost }(\alpha=0.96, \\
\text { AVE }=0.93)\end{array}$} & \multirow{5}{*}{$\begin{array}{l}\text { New measures } \\
\text { based on [93] }\end{array}$} & Social media offers good value & 0.92 \\
\hline & & Social media is cost-effective & 0.92 \\
\hline & & Attractive in terms of cost & 0.91 \\
\hline & & The cost of promotion is reasonable & 0.97 \\
\hline & & Social media enables me to communicate better with patients & 0.8 \\
\hline \multirow{3}{*}{$\begin{array}{l}\text { Perceived usefulness } \\
(\alpha=0.89, \mathrm{AVE}=0.87)\end{array}$} & \multirow{3}{*}{$\begin{array}{l}\text { New measures } \\
\text { based on [28] }\end{array}$} & Improves quality of patient care & 0.71 \\
\hline & & Increases knowledge sharing & 0.67 \\
\hline & & Improves job performance & 0.68 \\
\hline \multirow{4}{*}{$\begin{array}{l}\text { Usage behaviour }(\alpha=0.92, \\
\qquad \operatorname{AVE}=0.87)\end{array}$} & \multirow{4}{*}{$\begin{array}{c}\text { New measure } \\
\text { developed based } \\
\text { on [28] }\end{array}$} & I use social media to share medical knowledge with patients & 0.88 \\
\hline & & I follow several health professionals in various social media & 0.91 \\
\hline & & $\begin{array}{l}\text { I share available medical information using social media } \\
\text { platforms }\end{array}$ & 0.85 \\
\hline & & I use social media for self-promotion & 0.85 \\
\hline
\end{tabular}

The above table confirms that all composite reliabilities exceeded the baseline criterion of 0.70 [120]. The average variance extracted (AVE) for each construct is also greater than the baseline limit of 0.50 [121]. The factor loadings, and reliability scores were also found to be above the required threshold. Therefore, all constructs are retained for confirmatory analysis and all results indicate the instrument's convergent validity. During the assessment of multicollinearity, the correlation matrix (Table 3) confirmed that no correlation between any two items was above 0.8 ; thus, bivariate high collinearity did not exist. Construct correlations were compared with the square root of the AVE, and it was found that all square roots of the AVEs were consistently higher than the correlations between constructs. In this way, the discriminant validity of the constructs used in this research was confirmed [109].

Table 3. Bivariate correlations.

\begin{tabular}{|c|c|c|c|c|c|c|c|c|c|}
\hline & 1 & 2 & 3 & 4 & 5 & 6 & 7 & 8 & 9 \\
\hline 1. Content quality & 1 & & & & & & & & \\
\hline 2. Perceived risk & $0.297 * *$ & 1 & & & & & & & \\
\hline 3. Perceived credibility & $0.452 * *$ & $0.324 * *$ & 1 & & & & & & \\
\hline 4. Peer influence & $0.496^{* *}$ & $0.223 * *$ & $0.391 * *$ & 1 & & & & & \\
\hline 5. Supporting conditions & $0.243 * *$ & 0.092 & $0.192 *$ & 0.011 & 1 & & & & \\
\hline 6. Confirmation of expectations & $0.233^{* *}$ & $0.306^{* *}$ & $0.391 * *$ & $0.329 * *$ & $0.241 * *$ & 1 & & & \\
\hline 7. Perceived cost & $0.408^{* *}$ & $0.302 * *$ & $0.442 * *$ & $0.525 * *$ & $0.172 *$ & $0.532 * *$ & 1 & & \\
\hline 8. Perceived usefulness & $0.250 * *$ & $-0.216 * *$ & $0.238 * *$ & $0.325 * *$ & $0.334 *$ & $0.190 * *$ & $-0.178 *$ & 1 & \\
\hline 9. Usage behaviour & $0.364 * *$ & $0.201 * *$ & $0.323 * *$ & $0.561^{* *}$ & $0.189 *$ & $0.311^{* *}$ & $0.524^{* *}$ & 0.183 * & 1 \\
\hline
\end{tabular}

** Significant at the 0.001 level; * Significant at the 0.005 level.

\subsection{The Demographic Profile}

The completed survey includes $48 \%$ male participants and 52\% female participants. Regarding the participants' age range, 2\% were 18-29 years old, 30\% were in the 30-39 bracket, 35\% were $40-49$ years old, $25 \%$ were 50 to 59 and $8 \%$ were over 60 years of age. Regarding the participants' experience in healthcare, $48 \%$ had $1-15$ years, $48 \%$ had $16-30$ years, and $4 \%$ had more than 30 years. Table 4 summerises the patterns of personal and professional use of social media among health professionals.

In terms of personal use, it emerges that Facebook, YouTube, Twitter, and LinkedIn are the most popular social media applications. Facebook is the most frequently used platform as $47 \%$ are regular users of it. YouTube is the second most popular platform among health professionals ( $45 \%$ ). This is followed by $25 \%$ of respondents frequently using Twitter, and $21 \%$ of respondents' access LinkedIn. $15 \%$ of respondents employ various other social media platforms for personal use. However, concerning the professional use of social media, only 19\% use Facebook, 12\% use Twitter, 25\% use YouTube, 7\% utilise blog sites, 
$21 \%$ use LinkedIn and $11 \%$ use other platforms. This finding point towards limited use of social media for professional purposes.

Table 4. Health professionals' social media usage pattern.

\begin{tabular}{ccc}
\hline Type & Personal Use & Professional Use \\
\hline Facebook & $102 / 47 \%$ & $41 / 19 \%$ \\
Twitter & $55 / 25 \%$ & $27 / 12 \%$ \\
Instagram & $9 / 4 \%$ & $9 / 4 \%$ \\
YouTube & $98 / 45 \%$ & $54 / 25 \%$ \\
Blogs & $17 / 8 \%$ & $15 / 7 \%$ \\
LinkedIn & $47 / 21 \%$ & $47 / 21 \%$ \\
Others & $33 / 15 \%$ & $23 / 11 \%$ \\
\hline
\end{tabular}

\section{Results}

Hypothesis Testing

The individual measurement model fit was tested for all dependent and independent constructs included in the theoretical framework. CFA of the initial 36 items measurement model revealed the following model indices: $\mathrm{CMIN}=1393, \mathrm{df}=467$ and $\mathrm{CMIN} / \mathrm{df}$ ratio $=2.984 ; \mathrm{CFI}=0.857$; and RMSEA $=0.09$, indicating a scope for model refinement. Subsequently, an assessment of the modification indices (MI) was conducted [122]. Accordingly, seven items were excluded from different constructs to achieve a better fit to the data. This reduces the $\chi^{2}$ value to $408(\mathrm{df}, 224, p<0.001)$ and significantly improved other fit indices in the final overall measurement (CFA) model. The retained items in the construct measures suggest a satisfactory fit between data and the measurement model. The final overall measurement model was tested with 29 items during the SEM stage. The results of final CFA demonstrate an adequate model fit $\left(\chi^{2}=438.355 ; \mathrm{df}, 224, \chi^{2} / \mathrm{df}=1.957\right.$, RMSEA $=0.06, \mathrm{IFI}=0.95, \mathrm{TLI}=0.93$, and CFI $=0.95$ ).

The subsequent phase examined the structural model to test the structural relationship between measured variables and latent constructs. [109]. The SEM analysis indicated a reasonable model fit $\left(\chi^{2}=534.241 ; \mathrm{df}, 239, \chi^{2} / \mathrm{df}=2.235\right.$, RMSEA $=0.06$, IFI $=0.92, \mathrm{TLI}=0.93$, and CFI $=0.92)$. Furthermore, the research model explains $\left(R^{2}=47.6 \%\right)$ variance in social media usage behaviour, which indicates a moderate explanatory power as recommended by $\mathrm{Hu}$ and Bentler [123].

The $\mathrm{R}^{2}$ value of $47.6 \%$ is also consistent with the findings of a recent meta-analysis which showed that most of the TAM based studies explained $40-70 \%$ of variance in behavioural intention and actual usage [46]. Table 5 below provides an overview of the results of the hypothesis testing performed in SEM.

Table 5. SEM Results.

\begin{tabular}{cllcccc}
\hline Path & & & Path Coefficient & S.E. & C.R. & P \\
\hline H1: Content quality & $\rightarrow$ & Perceived usefulness & 0.360 & 0.160 & 2.752 & 0.012 \\
H2: Perceived credibility & $\rightarrow$ & Perceived usefulness & 0.423 & 0.117 & 3.274 & $* * *$ \\
H3: Perceived risks & $\rightarrow$ & Perceived usefulness & -0.600 & 0.103 & -5.849 & $* * *$ \\
H4: Peer influence & $\rightarrow$ & Perceived usefulness & 0.272 & 0.161 & 2.816 & $* * *$ \\
H5: Supporting conditions & $\rightarrow$ & Perceived usefulness & 0.428 & 0.199 & 2.062 & 0.019 \\
H6: Confirmation of expectations & $\rightarrow$ & Perceived usefulness & 0.282 & 0.087 & 3.620 & $* * *$ \\
H7: Perceived cost & $\rightarrow$ & Perceived usefulness & -0.201 & 0.093 & -2.164 & 0.020 \\
H8: Perceived usefulness & $\rightarrow$ & Usage behaviour & 0.142 & 0.063 & 2.241 & 0.022 \\
\hline
\end{tabular}




\section{Discussion}

The results demonstrate that all hypothesised relationships are supported. This research confirms that content quality (H1) is a significant predictor of perceived usefulness $(p<0.05)$. The finding is consistent with previous studies in different contexts which have found that online content quality positively influences the notion of perceived usefulness in digital information exchange settings $[124,125]$. This study concludes that if the health professionals perceive that social media channels facilitate dissemination of high-quality health-related content, they will use it more extensively.

The insertion of perceived credibility (H2) as an independent variable also provides a new perspective for studying social media acceptance research in healthcare. Although several studies [55,126-128] have looked at the role of trust as a direct antecedent of behavioural intentions, this study investigates the effect of credibility on perceived usefulness in the context of social media technologies. The SEM analysis indicates that perceived credibility is significantly associated with the perception of usefulness $(p<0.01)$ and this finding is consistent with previous studies [59,129]. Therefore, if health professionals perceive social media as a credible platform to professionally interact with their patients, they will perceive it as useful. Therefore, the role of credibility is pivotal in shaping productive relationships between health professionals and patients.

Consistent with prior research [6,63], findings confirm a significant and negative association $(p<0.01)$ between perceived risks and perceived usefulness $(\mathrm{H} 3)$. This result reflects the health professionals' concern about privacy and confidentiality, the main items that represent the construct of perceived risk in the healthcare context. Privacy threats as a universal phenomenon are playing a critical role in the communication mechanisms of healthcare professionals and patients.

The study has also examined the relationship between peer influence and perceived usefulness. It confirms there is a significant association $(p<0.05)$ between these two constructs. The findings are consistent with prior studies [45,74,102]. As mentioned earlier, past studies predominantly examined the influence of peers in assessing information technology usage behaviour. However, studies in relation to the influence of peers on social media usage decisions in healthcare are relatively scarce. The results confirm that peer influence is a significant predictor of health professionals' perceived usefulness of social media [130]. The social aspect of social media motivates users to embrace the way information and knowledge is disseminated between health professionals, their patients and members of the public [131]. Consequently, establishing a network with other relevant players is an essential factor in community wellbeing.

The relationship between supporting conditions and perceived usefulness (H5) was also supported $(p<00.05)$. This result is consistent with prior research which exhibited a positive effect of supporting conditions on perceived usefulness [132]. The results indicate that a favourable environment helps to reduce uncertainty in relation to the usage of social media by health professionals. Thus, a favourable social, technical and organisational environment will help healthcare providers to realise the full potential of social media [133-135].

The result indicated a significant relationship (H6) between confirmation of expectations and perceived usefulness $(p<0.01)$. The finding is consistent with the notion that the higher the confirmation, the higher the perceived usefulness [85-90]. Moreover, this research further validates that physicians are likely to use social media when its benefits in healthcare are confirmed.

The effect of perceived cost was assumed to be a strong indicator of social media adoption (H7). The results indicate that the perceived cost of social media negatively influences $(p<0.05)$ the perception of usefulness. Prior research highlighted cost as an important factor affecting users' behavioural intention [124-127]. Thus, this research confirmed some of the arguments put forward in the literature [82,128]. Extant literature revealed that social media applications make it possible for healthcare professionals to engage with their patients, enhance brand image and increase patient satisfaction in a very 
cost-effective way $[46,71,74,77,129,130]$. Thus, professional use of social media would allow physicians to share and exchange health information on a large scale [60].

Finally, the findings demonstrate a significant association between perceived usefulness (H8) and usage behaviour $(p<0.05)$, confirming the notion that health professionals' perception of usefulness is a key predictor of their actual social media usage behaviour.

\section{Conclusions and Implications}

This study contributes to the limited research on social media in the healthcare context by building on previous research $[24,26]$. Prior technology adoption theories were mostly operationalised without taking into account the characteristics of social media. Although many researchers have tested the existing adoption theories in the healthcare context, the unique characteristics of social media needed a more context-specific approach to model development. This research enriches the traditional technology acceptance model (TAM) by operationalising additional constructs such as content quality, perceived credibility, perceived risk, peer influence, supporting conditions, confirmation of expectations and perceived cost affecting the social media usage decisions of Australian healthcare professionals. These constructs were formulated, operationalised, and tested exclusively, drawing on the social media use behaviours of healthcare professionals.

Prior research explored the potential of social media technologies in healthcare [2-7]. However, compared to previous studies, this research backed its arguments with empirical data collected from the healthcare industry but also explored and identified new factors that are relevant to social media adoption behaviours. This research operationalised some relatively unknown factors regarding the usage of social media in healthcare.

Current wisdom suggests that although social media can alleviate many challenges pertaining to the practical, social and emotional aspects of healthcare service delivery, there is a growing concern in the minds of healthcare professionals about some negative aspects of social media usage in their medical practice. The findings point towards the need for more strategic initiatives concerning security related issues associated with health professionals. Healthcare authorities need to undertake practical initiatives to attract health professionals in this interactive sphere by firstly, promoting the benefits, and secondly, ensuring the availability of support structures to improve community health.

The findings also point towards the need to raise more awareness, training, and support for practitioners so that the adoption trends of social media are maintained and further enhanced. The findings also point towards the fear or scepticism in health professionals minds concerning professional use or abuse of social media. This scepticism is attributed to the challenges associated with poor content quality, credibility issues, perceived risk and unfavourable supporting conditions.

The study findings may provide an opportunity for healthcare providers and policymakers to understand and take necessary actions with regard to the current status of healthcare practitioners perceptions of the potential factors affecting the usage of social media for health communication. Healthcare providers, administrators and system professionals can consider the relevant factors affecting adoption behaviour and formulate a clear social media usage guideline, offering health professionals advice on how to maximise potential benefits through engagement with social media. These insights could be used in developing social media guidelines effectively and to maximise the benefits for the specific needs of the health community. This is paramount, as there is currently a widespread scepticism about the viability of social media applications in the healthcare domain [6].

To sum up, adequate knowledge of the factors driving adoption behaviour discussed above may provide guidelines for the healthcare sector. Appropriate strategies that address these issues and improve the current status of social media usage amongst Australian healthcare professionals and consumers should be designed. 


\section{Limitations and Future Research}

Like any other research, this study has its limitations. This research has been undertaken in an Australian context which tends to limit the generalisation of the findings internationally. Future research can overcome this limitation by using large samples drawn from other Western countries with similar social and economic characteristics, for example, Canada, New Zealand, the UK and the USA. Furthermore, the cross-sectional design does not consider the responses at different time intervals. Notably, some constructs (like usage behaviour) need a period of time to pass for them to be measured correctly. This is thought to be a limitation of most TAM-based research. Future studies may take the form of comparative studies or judge the pre-adoption and post-adoption behaviour of social media in healthcare. The time factor is worth investigating where some time is needed for the conclusive data to emerge and mean something. The issue of generalisability is a widely known limitation in most of the research on technology acceptance. Finally, the research posed considerable challenges to access health professionals who are active users of social media and could be recruited for the study. Due to the busy nature of the profession, only a small number of participants was enthused to participate in this research since they are usually too busy with their everyday tasks. However, the sample was chosen not only for practical reasons and convenience but also because healthcare professionals are amongst those whose opinions and perceptions will influence the adoption of social media in healthcare organisations.

Author Contributions: Conceptualization, M.I.K., M.A.S. and A.Q.; methodology, M.I.K. and A.Q.; Data analysis, M.A.S. and M.I.K.; writing-original draft preparation, M.I.K., M.A.S. and A.Q.; writing-review and editing, M.I.K.; supervision, A.Q. All authors have read and agreed to the published version of the manuscript.

Funding: This research received no external funding.

Institutional Review Board Statement: The study was conducted according to the guidelines of the Declaration of Helsinki and approved by the University of Canberra, Human Research Ethics Committee (Approve project 15-234, 3/11/2015).

Informed Consent Statement: Informed consent was obtained from all subjects involved in the study.

Data Availability Statement: Data sharing is not applicable to this article.

Conflicts of Interest: The authors declare no conflict of interest.

\section{References}

1. Fernández-Luque, L.; Bau, T. Health and social media: Perfect storm of information. Healthc. Inform. Res. 2015, 21, 67-73. [CrossRef] [PubMed]

2. Leary, V.G.; Grant, G. Social media in healthcare. In Proceedings of the 50th Hawaii International Conference on System Sciences, Puako, HI, USA, 4-7 January 2017.

3. Park, A.; Bowling, J.; Shaw, G., Jr.; Li, C.; Chen, S. Adopting social media for improving health opportunities and challenges. North Carol. Med. J. 2019, 80, 240-243. [CrossRef] [PubMed]

4. Gabarron, E.; Bradway, M.; Fernandez-Luque, L.; Chomutare, T.; Hansen, A.H.; Wynn, R.; Årsand, E. Social media for health promotion in diabetes: Study protocol for a participatory public health intervention design. BMC Health Serv. Res. 2018, 18, 1-5. [CrossRef]

5. Barnes, S.S.; Kaul, V.; Kudchadkar, S.R. Social media engagement and the critical care medicine community. J. Intensive Care Med. 2019, 34, 175-182. [CrossRef] [PubMed]

6. Moorhead, S.A.; Hazlett, D.E.; Harrison, L.; Carroll, J.K.; Irwin, A.; Hoving, C. A new dimension of health care: Systematic review of the uses, benefits, and limitations of social media for health communication. J. Med. Internet Res. 2013, 15, 4. [CrossRef]

7. Korda, H.; Itani, Z. Harnessing social media for health promotion and behavior change. Health Promot. Pract. 2013, 14, 15-23. [CrossRef]

8. Sarasohn-Kahn, J. The Wisdom of Patients: Health Care Meets Online Social Media; California HealthCare Foundation: Oakland, CA, USA, 2008.

9. Sarringhaus, M.M. The great divide: Social media's role in bridging healthcare's generational shift. J. Healthc. Manag. 2011, 56, 235-244. 
10. Fisher, J.; Clayton, M. Who gives a tweet: Assessing patients' interest in the use of social media for health care. Worldviews Evid. Based Nurs. 2012, 9, 100-108. [CrossRef]

11. Lambert, K.M.; Barry, P.; Stokes, G. Risk management and legal issues with the use of social media in the healthcare setting. J. Healthc. Risk Manag. 2012, 31, 41-47. [CrossRef]

12. Andersen, K.N.; Medaglia, R.; Henriksen, H.Z. Social media in public health care: Impact domain propositions. Gov. Inf. Q. 2012, 29, 462-469. [CrossRef]

13. Wicks, P.; Massagli, M.; Frost, J.; Brownstein, C.; Okun, S.; Vaughan, T.; Bradley, R.; Heywood, J. Sharing health data for better outcomes on PatientsLikeMe. J. Med. Internet Res. 2010, 12, e19. [CrossRef] [PubMed]

14. Miller, A.R.; Tucker, C. Active social media management: The case of health care. Inf. Syst. Res. 2013, 24, 52-70. [CrossRef]

15. Chretien, K.C.; Greysen, S.R.; Chretien, J.P.; Kind, T. Online posting of unprofessional content by medical students. JAMA 2009, 302, 1309-1315. [CrossRef]

16. McKee, R. Ethical issues in using social media for health and health care research. Health Policy 2013, 110, 298-301. [CrossRef] [PubMed]

17. Grobler, C.; Dhai, A. Social media in the healthcare context: Ethical challenges and recommendations. S. Afr. J. Bioeth. Law 2016, 9 , 22-25. [CrossRef]

18. Sahin, I. Detailed review of Rogers' diffusion of innovations theory and educational technology-related studies based on Rogers' theory. Turk. Online J. Educ. Technol.-TOJET 2006, 5, 14-23.

19. Antheunis, M.L.; Tates, K.; Nieboer, T.E. Patients' and health professionals' use of social media in health care: Motives, barriers and expectations. Patient Educ. Couns. 2013, 92, 426-431. [CrossRef] [PubMed]

20. Cuan-Baltazar, J.Y.; Muñoz-Perez, M.J.; Robledo-Vega, C.; Pérez-Zepeda, M.F.; Soto-Vega, E. Misinformation of COVID-19 on the internet: Infodemiology study. JMIR Public Health Surveill. 2020, 6, e18444. [CrossRef]

21. Kasemsap, K. Professional and business applications of social media platforms. In Social Entrepreneurship: Concepts, Methodologies, Tools, and Applications; IGI Global: Hershey, PA, USA, 2019; pp. 824-847.

22. Kouzy, R.; Abi Jaoude, J.; Kraitem, A.; El Alam, M.B.; Karam, B.; Adib, E.; Zarka, J.; Traboulsi, C.; Akl, E.W.; Baddour, K. Coronavirus goes viral: Quantifying the COVID-19 misinformation epidemic on Twitter. Cureus 2020, 12, e7255. [CrossRef]

23. Smailhodzic, E.; Hooijsma, W.; Boonstra, A.; Langley, D.J. Social media use in healthcare: A systematic review of effects on patients and on their relationship with healthcare professionals. BMC Health Serv. Res. 2016, 16, 442. [CrossRef]

24. Kind, T.; Greysen, S.R.; Chretien, K.C. Pediatric clerkship directors' social networking use and perceptions of online professionalism. Acad. Pediatrics 2012, 12, 142-148. [CrossRef] [PubMed]

25. Brown, J.; Ryan, C.; Harris, A. How doctors view and use social media: A national survey. J. Med. Internet Res. 2014, 16, 12. [CrossRef] [PubMed]

26. Usher, W. Types of social media (Web 2.0) used by Australian allied health professionals to deliver early twenty-first-century practice promotion and health care. Social Work Health Care 2011, 50, 305-329. [CrossRef]

27. McGowan, B.S.; Wasko, M.; Vartabedian, B.S.; Miller, R.S.; Freiherr, D.D.; Abdolrasulnia, M. Understanding the factors that influence the adoption and meaningful use of social media by physicians to share medical information. J. Med. Internet Res. 2012, 14, 5. [CrossRef] [PubMed]

28. Davis, F.D. Perceived usefulness, perceived ease of use, and user acceptance of information technology. MIS Q. 1989, 13, 319-340. [CrossRef]

29. Šumak, B.; Heričko, V.; PušNik, M. A meta-analysis of e-learning technology acceptance: The role of user types and e-learning technology types. Comput. Hum. Behav. 2011, 27, 2067-2077. [CrossRef]

30. Scherer, R.; Siddiq, F.; Tondeur, J. The technology acceptance model (TAM): A meta-analytic structural equation modeling approach to explaining teachers' adoption of digital technology in education. Comput. Educ. 2019, 128, 13-35. [CrossRef]

31. Nadri, H.; Rahimi, B.; Lotfnezhad, A.H.; Samadbeik, M.; Garavand, A. Factors affecting acceptance of hospital information systems based on extended technology acceptance model: A case study in three paraclinical departments. Appl. Clin. Inform. 2018, 9, 238. [CrossRef]

32. Palos-Sanchez, P.R.; Hernandez-Mogollon, J.M.; Campon-Cerro, A.M. The behavioral response to location-based services: An examination of the influence of social and environmental benefits, and privacy. Sustainability 2017, 9, 1988. [CrossRef]

33. Ajzen, I.; Fishbein, M. Understanding Attitudes and Predicting Social Behavior; Pearson: London, UK, 1980.

34. Davis, F.D.; Bagozzi, R.P.; Warshaw, P.R. User acceptance of computer technology: A comparison of two theoretical models. Manag. Sci. 1989, 35, 982-1003. [CrossRef]

35. Venkatesh, V.; Davis, F.D. A theoretical extension of the technology acceptance model: Four longitudinal field studies. Manag. Sci. 2000, 46, 186-204. [CrossRef]

36. Koh, C.E.; Prybutok, V.R.; Ryan, S.D.; Wu, Y. A model for mandatory use of software technologies: An integrative approach by applying multiple levels of abstraction of informing science. Inf. Sci. 2010, 13, 177-203.

37. Yang, H.-D.; Yoo, Y. It's all about attitude: Revisiting the technology acceptance model. Decis. Support Syst. 2004, 38, 19-31. [CrossRef]

38. Abdullah, F.; Ward, R.; Ahmed, E. Investigating the influence of the most commonly used external variables of TAM on students Perceived Ease of Use (PEOU) and Perceived Usefulness (PU) of e-portfolios. Comput. Hum. Behav. 2016, 63, 75-90. [CrossRef] 
39. Kucukusta, D.; Law, R.; Besbes, A.; Legohérel, P. Re-examining perceived usefulness and ease of use in online booking. Int. J. Contemp. Hosp. Manag. 2015, 27, 185-198. [CrossRef]

40. Ong, C.S.; Lai, J.Y.; Wang, Y.S. Factors affecting engineers' acceptance of asynchronous e-learning systems in high-tech companies. Inform. Manag. 2004, 41, 795-804. [CrossRef]

41. Chismar, W.G.; Wiley-Patton, S. Does the extended technology acceptance model apply to physicians. In Proceedings of the 36th Annual Hawaii International Conference on System Sciences, Big Island, HI, USA, 6-9 January 2003.

42. Lin, C.; Lin, I.-C.; Roan, J. Barriers to physicians' adoption of healthcare information technology: An empirical study on multiple hospitals. J. Med. Syst. 2012, 36, 1965-1977. [CrossRef]

43. Phang, C.W.; Li, Y.; Sutanto, J.; Kankanhalli, A. Senior citizens' adoption of e-government: In quest of the antecedents of perceived usefulness. In Proceedings of the 38th Annual Hawaii International Conference on System Sciences, Big Island, HI, USA, 6 January 2005; p. 130a.

44. Davis, F.D. User acceptance of information technology: System characteristics, user perceptions and behavioral impacts. Int. J. Man Mach. Stud. 1993, 38, 475-487. [CrossRef]

45. Venkatesh, V.; Morris, M.G.; Davis, G.B.; Davis, F.D. User acceptance of information technology: Toward a unified view. MIS Q. 2003, 27, 425-478. [CrossRef]

46. Holden, R.J.; Karsh, B.-T. The technology acceptance model: Its past and its future in health care. J. Biomed. Inform. 2010, 43, 159-172. [CrossRef]

47. Delone, W.H.; McLean, E.R. The DeLone and McLean model of information systems success: A ten-year update. J. Manag. Inf. Syst. 2003, 19, 9-30.

48. DeLone, W.H.; McLean, E.R. Information systems success: The quest for the dependent variable. Inf. Syst. Res. 1992, 3, 60-95. [CrossRef]

49. Al-Gahtani, S.S. Modeling the electronic transactions acceptance using an extended technology acceptance model. Appl. Comput. Inform. 2011, 9, 47-77. [CrossRef]

50. Lopez, D.; Blobel, B.; Gonzalez, C. Information quality in healthcare social media-An architectural approach. Health Technol. 2016, 6, 17-25. [CrossRef]

51. Gutierrez, N.; Kindratt, T.B.; Pagels, P.; Foster, B.; Gimpel, N.E. Health literacy, health information seeking behaviors and internet use among patients attending a private and public clinic in the same geographic area. J. Community Health 2014, 39, 83-89. [CrossRef]

52. Mohammadi, F.; Abrizah, A.; Nazari, M. Is the information fit for use? Exploring teachers perceived information quality indicators for Farsi web-based learning resources. Malays. J. Libr. Inf. Sci. 2017, 20, 1.

53. Alsabawy, A.Y.; Cater-Steel, A.; Soar, J. Soar. Determinants of perceived usefulness of e-learning systems. Comput. Hum. Behav. 2016, 64, 843-858. [CrossRef]

54. Considine, D.M. Social Media for Health Professionals-Benefits and Pitfalls. Available online: https://www.doctorportal.com. au/social-media-for-health-professionals-benefits-and-pitfalls / (accessed on 17 March 2018).

55. Gefen, D.; Karahanna, E.; Straub, D.W. Trust and TAM in online shopping: An integrated model. MIS Q. 2003, 27, 51-90. [CrossRef]

56. Hou, J.; Shim, M. The role of provider-patient communication and trust in online sources in Internet use for health-related activities. J. Health Commun. 2010, 15, 186-199. [CrossRef]

57. Bansal, G.; Gefen, D. The impact of personal dispositions on information sensitivity, privacy concern and trust in disclosing health information online. Decis. Support Syst. 2010, 49, 138-150. [CrossRef]

58. Van Der Velden, M.; El Emam, K. Not all my friends need to know: A qualitative study of teenage patients, privacy, and social media. J. Am. Med. Inform. Assoc. 2013, 20, 16-24. [CrossRef] [PubMed]

59. Lin, W.-Y.; Zhang, X.; Song, H.; Omori, K. Health information seeking in the Web 2.0 age: Trust in social media, uncertainty reduction, and self-disclosure. Comput. Hum. Behav. 2016, 56, 289-294. [CrossRef]

60. Jacoby, J.; Kaplan, L.B. The components of perceived risk. In Proceedings of the Third Annual Conference of the Association for Consumer Research, Chicago, IL, USA, 3-5 November 1972.

61. Stone, R.N.; Grønhaug, K. Perceived risk: Further considerations for the marketing discipline. Eur. J. Mark. 1993, 27, 39-50. [CrossRef]

62. Mitra, K.; Reiss, M.C.; Capella, L.M. An examination of perceived risk, information search and behavioral intentions in search, experience and credence services. J. Serv. Mark. 1999, 13, 208-228. [CrossRef]

63. Rahman, M.M.; Sloan, T. User adoption of mobile commerce in Bangladesh: Integrating perceived risk, perceived cost and personal awareness with TAM. Int. Technol. Manag. Rev. 2017, 6, 103-124. [CrossRef]

64. Crane, G.M.; Gardner, J.M. Pathology image-sharing on social media: Recommendations for protecting privacy while motivating education. AMA J. Ethics 2016, 18, 817.

65. Melnik, T. Avoiding violations of patient privacy with social media. J. Nurs. Regul. 2013, 3, 39-46. [CrossRef]

66. Al-Muhtadi, J.; Shahzad, B.; Saleem, K.; Jameel, W.; Orgun, M.A. Cybersecurity and privacy issues for socially integrated mobile healthcare applications operating in a multi-cloud environment. Health Inform. J. 2019, 25, 315-329. [CrossRef]

67. Hader, A.L.; Brown, E.D. LEGAL BRIEFS. Patient Privacy and Social Media. AANA J. 2010, 78, $270-274$. 
68. Hawn, C. Take two aspirin and tweet me in the morning: How Twitter, Facebook, and other social media are reshaping health care. Health Aff. 2009, 28, 361-368. [CrossRef]

69. Cain, J. Social media in health care: The case for organizational policy and employee education. Am. J. Health Syst. Pharm. 2011, 68, 1036-1040. [CrossRef] [PubMed]

70. Lagu, T.; Kaufman, E.J.; Asch, D.A.; Armstrong, K. Content of weblogs written by health professionals. J. Gen. Intern. Med. 2008, 23, 1642. [CrossRef] [PubMed]

71. Chretien, K.C.; Azar, J.; Kind, T. Physicians on twitter. JAMA 2011, 305, 566-568. [PubMed]

72. Thompson, L.A.; Black, E.; Duff, W.P.; Black, N.P.; Saliba, H.; Dawson, K. Protected health information on social networking sites: Ethical and legal considerations. J. Med. Internet Res. 2011, 13, 1. [CrossRef] [PubMed]

73. Farnan, J.M.; Snyder Sulmasy, L.; Worster, B.K.; Chaudhry, H.J.; Rhyne, J.A.; Arora, V.M.; American College of Physicians Ethics; Professionalism and Human Rights Committee, American College of Physicians Council of Associates; Federation of State Medical Boards Special Committee on Ethics and Professionalism. Online medical professionalism: Patient and public relationships: Policy statement from the American College of Physicians and the Federation of State Medical Boards. Ann. Intern. Med. 2013, 158, 620-627. [CrossRef]

74. Vanneste, D.; Vermeulen, B.; Declercq, A. Healthcare professionals' acceptance of BelRAI, a web-based system enabling personcentred recording and data sharing across care settings with interRAI instruments: A UTAUT analysis. BMC Med. Inform. Decis. Mak. 2013, 13, 1-4. [CrossRef]

75. Panahi, S.; Watson, J.; Partridge, H. Social media and physicians: Exploring the benefits and challenges. Health Inform. J. 2016, 22, 99-112. [CrossRef]

76. Martinasek, M.P.; Panzera, A.D.; Schneider, T.; Lindenberger, J.H.; Bryant, C.A.; McDermott, R.J.; Couluris, M. Benefits and barriers of pediatric healthcare providers toward using social media in asthma care. Am. J. Health Educ. 2011, 42, $213-221$. [CrossRef]

77. Vitak, J.; Ellison, N.B. There'sa network out there you might as well tap': Exploring the benefits of and barriers to exchanging informational and support-based resources on Facebook. New Media Soc. 2013, 15, 243-259. [CrossRef]

78. Kamal, S.; Ayesha, M.S.; Priyanka, K. Investigating acceptance of telemedicine services through an extended technology acceptance model (TAM). Technol. Soc. 2020, 60, 101212. [CrossRef]

79. Surani, Z.; Hirani, R.; Elias, A.; Quisenberry, L.; Varon, J.; Surani, S.; Surani, S. Social media usage among health care providers. BMC Res. Notes 2017, 10, 654. [CrossRef] [PubMed]

80. Murire, O.T.; Cilliers, L. Social media adoption among lecturers at a traditional university in Eastern Cape Province of South Africa. SA J. Inform. Manag. 2017, 19, 6. [CrossRef]

81. Puspitasari, I.; Firdauzy, A. Characterizing consumer behavior in leveraging social media for e-patient and health-related activities. Int. J. Environ. Res. Public Health 2019, 16, 3348. [CrossRef] [PubMed]

82. Peñarroja, V.; Sánchez, J.; Gamero, N.; Orengo, V.; Zornoza, A.M. The influence of organizational facilitating conditions and technology acceptance factors on the effectiveness of virtual communities of practice. Behav. Inf. Technol. 2019, 38, 845-857. [CrossRef]

83. Brown, S.A.; Venkatesh, V.; Kuruzovich, J.; Massey, A.P. Expectation confirmation: An examination of three competing models. Organ. Behav. Hum. Decis. Process. 2008, 105, 52-66. [CrossRef]

84. Wijaya, I.; Rai, A.; Hariguna, T. The impact of customer experience on customer behavior intention use in social media commerce, an extended expectation confirmation model: An empirical study. Manag. Sci. Lett. 2019, 12, 2009-2020. [CrossRef]

85. Bhattacherjee, A. Understanding information systems continuance: An expectation-confirmation model. MIS Q. 2001, 351-370. [CrossRef]

86. Hew, J.J.; Lee, V.H.; Ooi, K.B.; Lin, B. Mobile social commerce: The booster for brand loyalty? Comput. Hum. Behav. 2016, 59, 142-154. [CrossRef]

87. Kim, B. An empirical investigation of mobile data service continuance: Incorporating the theory of planned behavior into the expectation-confirmation model. Expert Syst. Appl. 2010, 37, 7033-7039. [CrossRef]

88. Hariguna, T.; Lai, M.T.; Hung, C.W.; Chen, S.C. Understanding information system quality on public e-government service intention: An empirical study. Int. J. Innov. Sustain. Dev. 2017, 11, 271-290. [CrossRef]

89. Park, E. User acceptance of smart wearable devices: An expectation-confirmation model approach. Telemat. Inform. 2020, 47, 101318. [CrossRef]

90. Chow, W.S.; Shi, S. Investigating students' satisfaction and continuance intention toward e-learning: An Extension of the expectation-confirmation model. Procedia-Soc. Behav. Sci. 2014, 141, 1145-1149. [CrossRef]

91. Wixom, B.H.; Todd, P.A. A theoretical integration of user satisfaction and technology acceptance. Inform. Syst. Res. 2005, 16, 85-102. [CrossRef]

92. Chuttur, M.Y. Overview of the technology acceptance model: Origins, developments and future directions. Work. Pap. Inform. Syst. 2009, 37, 9-37.

93. Kim, S.H. Moderating effects of job relevance and experience on mobile wireless technology acceptance: Adoption of a smartphone by individuals. Inf. Manag. 2008, 45, 387-393. [CrossRef]

94. Roger, E. Diffusion of Innovations; The Free Press: New York, NY, USA, 1995. 
95. Pearson, A.; Suresh, T.; Chris, G. The role of e-service quality and information quality in creating perceived value: Antecedents to web site loyalty. Inf. Syst. Manag. 2012, 29, 201-215. [CrossRef]

96. Sripalawat, J.; Thongmak, M.; Ngramyarn, A. M-banking in metropolitan Bangkok and a comparison with other countries. J. Comput. Inf. Syst. 2011, 51, 67-76.

97. Yarbrough, A.K.; Smith, T.B. Technology acceptance among physicians: A new take on TAM. Med. Care Res. Rev. 2007, 64, 650-672. [CrossRef]

98. Burton-Jones, A.; Straub, D.W., Jr. Reconceptualizing system usage: An approach and empirical test. Inf. Syst. Res. 2006, 17, 228-246. [CrossRef]

99. Legris, P.; Ingham, J.; Collerette, P. Why do people use information technology? A critical review of the technology acceptance model. Inform. Manag. 2003, 40, 191-204. [CrossRef]

100. Aluri, A.; Tucker, E. Social influence and technology acceptance: The use of personal social media as a career enhancement tool among college students. J. Hosp. Tour. Educ. 2015, 27, 48-59. [CrossRef]

101. Westin, A.F. Privacy and freedom. Wash. Lee Law Rev. 1968, 25, 166.

102. Venkatesh, V.; Thong, J.Y.; Xu, X. Consumer acceptance and use of information technology: Extending the unified theory of acceptance and use of technology. MIS Q. 2012, 36, 157-178. [CrossRef]

103. Lee, M.C. Explaining and predicting users' continuance intention toward e-learning: An extension of the expectation-confirmation model. Comput. Educ. 2010, 54, 506-516. [CrossRef]

104. Wei, T.T.; Marthandan, G.; Chong, A.Y.L.; Ooi, K.B.; Arumugam, S. What drives Malaysian m-commerce adoption? An empirical analysis. Ind. Manag. Data Syst. 2009, 109, 370-388.

105. Chang, I.-C.; Hwang, H.-G.; Hung, W.-F.; Li, Y.-C. Physicians' acceptance of pharmacokinetics-based clinical decision support systems. Expert Syst. Appl. 2007, 33, 296-303. [CrossRef]

106. Bryman, A.; Bell, E. Business Research Methods; Oxford University Press: New York, NY, USA, 2015.

107. Ryan, G.W.; Bernard, H.R. Techniques to identify themes. Field Methods 2003, 15, 85-109. [CrossRef]

108. Tabachnick, B.G.; Fidell, L.S. Using Multivariate Statistics; Pearson: London, UK, 2007.

109. Hair, J.F.; Black, W.C.; Babin, B.J.; Anderson, R.E.; Tatham, R.L. Multivariate Data Analysis, 6th ed.; Pearson: London, UK, 2006.

110. Reyes-Menendez, A.; Saura, J.R.; Palos-Sanchez, P.R.; Alvarez-Garcia, J. Understanding user behavioral intention to adopt a search engine that promotes sustainable water management. Symmetry 2018, 10, 584. [CrossRef]

111. Chin, W.W.; Todd, P.A. On the use, usefulness, and ease of use of structural equation modeling in MIS research: A note of caution. MIS Q. 1995, 19, 237-246. [CrossRef]

112. Byrne, B.M. Structural Equation Modeling with AMOS: Basic Concepts, Applications, and Programming (Multivariate Applications Series); Taylor and Francis: Oxfordshire, UK, 2010; Volume 396, p. 7384.

113. Cummins, R.A.; Gullone, E. Why we should not use 5-point Likert scales: The case for subjective quality of life measurement. Proc. Second. Int. Conf. Qual. Life Cities 2000, 74, 93.

114. Finstad, K. Response interpolation and scale sensitivity: Evidence against 5-point scales. J. Usability Stud. 2010, 5, 104-110.

115. Featherman, M.S.; Pavlou, P.A. Predicting e-services adoption: A perceived risk facets perspective. Int. J. Hum.-Comput. Stud. 2003, 59, 451-474. [CrossRef]

116. Duyck, P.; Pynoo, B.; Devolder, P.; Voet, T.; Adang, L.; Vercruysse, J. User acceptance of a picture archiving and communication system. Methods Inf. Med. 2008, 47, 149-156. [PubMed]

117. Bhattacherjee, A.; Hikmet, N. Physicians' resistance toward healthcare information technology: A theoretical model and empirical test. Eur. J. Inf. Syst. 2007, 16, 725-737. [CrossRef]

118. De Kerviler, G.; Demoulin, N.T.; Zidda, P. Adoption of in-store mobile payment: Are perceived risk and convenience the only drivers? J. Retail. Consum. Serv. 2016, 31, 334-344. [CrossRef]

119. Chau, P.Y.; Hu, P.J.-H. Investigating healthcare professionals' decisions to accept telemedicine technology: An empirical test of competing theories. Inf. Manag. 2002, 39, 297-311. [CrossRef]

120. Hair, J.F. Research Methods for Business; John Wiley \& Sons: Hoboken, NJ, USA, 2007.

121. Fornell, C.; Larcker, D.F. Structural equation models with unobservable variables and measurement error: Algebra and statistics. J. Mark. Res. 1981, 18, 382-388. [CrossRef]

122. Byrne, B.M. Structural equation modeling: Perspectives on the present and the future. Int. J. Test. 2001, 1, 327-334.

123. Hu, L.T.; Bentler, P.M. Cutoff criteria for fit indexes in covariance structure analysis: Conventional criteria versus new alternatives. J. Econom. Struct. Equ. Modeling 1999, 6, 1-55. [CrossRef]

124. Machdar, N.M. The effect of information quality on Perceived usefulness and ease of ose. Bus. Entrep. Rev. 2019, 15, 131-146.

125. Saeed, K.A.; Abdinnour-Helm, S. Examining the effects of information system characteristics and perceived usefulness on post adoption usage of information systems. Inf. Manag. Decis. 2008, 45, 376-386. [CrossRef]

126. Fuller, M.A.; Serva, M.A.; Baroudi, J. Clarifying the integration of trust and TAM in e-commerce environments: Implications for systems design and management. IEEE Trans. Eng. Manag. 2010, 57, 380-393.

127. Chaouali, W.; Yahia, I.B.; Souiden, N. The interplay of counter-conformity motivation, social influence, and trust in customers' intention to adopt Internet banking services: The case of an emerging country. J. Retail. Consum. Serv. 2016, 28, 209-218. [CrossRef]

128. Ranaweera, H. Perspective of trust towards e-government initiatives in Sri Lanka. SpringerPlus 2016, 5, 22. [CrossRef] [PubMed] 
129. Mou, J.; Shin, D.-H.; Cohen, J. Understanding trust and perceived usefulness in the consumer acceptance of an e-service: A longitudinal investigation. Behav. Inform. Technol. 2017, 36, 125-139. [CrossRef]

130. Hanson, C.; West, J.; Neiger, B.; Thackeray, R.; Barnes, M.; Mcintyre, E. Use and acceptance of social media among health educators. Am. J. Health Educ. 2011, 42, 197-204. [CrossRef]

131. Williams, M.; Rana, N.; Dwivedi, Y.; Lal, B. Is UTAUT really used or just cited for the sake of it? A systematic review of citations of UTAUT's originating article. ECIS 2011 Proceedings 231.

132. Teo, T. Modeling the determinants of pre-service teachers' perceived usefulness of e-learning. Campus Wide Inf. Syst. 2011, 28, 124-140. [CrossRef]

133. Chretien, K.C.; Kind, T. Social media and clinical care: Ethical, professional, and social implications. Circulation 2013, 127, 1413-1421. [CrossRef]

134. Merolli, M.; Gray, K.; Martin-Sanchez, F. Health outcomes and related effects of using social media in chronic disease management: A literature review and analysis of affordances. J. Biomed. Inform. 2013, 46, 957-969. [CrossRef]

135. Tao, D.; Wang, T.; Wang, T.; Zhang, T.; Zhang, X.; Qu, X. A systematic review and meta-analysis of user acceptance of consumeroriented health information technologies. Comput. Hum. Behav. 2020, 104, 106147. [CrossRef] 